\title{
Tailoring participatory action research to deal with the latent problem of an invasive alien vine on Saba, Caribbean Netherlands
}

\author{
Jetske Vaas $^{1}(\mathbb{D}) \cdot$ Peter P. J. Driessen ${ }^{1} \cdot$ Mendel Giezen $^{2} \cdot$ Frank van Laerhoven $^{1} \cdot$ Martin J. Wassen $^{1}$
}

Received: 7 February 2019 / Accepted: 16 January 2020 / Published online: 22 February 2020

(C) The Author(s) 2020

\begin{abstract}
Participatory action research (PAR) is an approach for fully co-creating research into environmental problems with the public. We argue this is mostly done for manifest environmental problems that clearly threaten livelihoods and have highly predictable impacts. But the conventional PAR approach is not suitable when the impacts are poorly understood and pose a low threat to livelihoods. Such latent environmental problems do not have a clear conflict to be resolved; instead, the community's inertia should be overcome. In this article, we develop what we call the PAR-L approach, for which we present a step-by-step guide and an evaluation framework. We then demonstrate this approach on the latent problem of the invasive alien Coralita vine (Antigonon leptopus) on Saba (Caribbean Netherlands) and find that it results in thorough understanding of the community inertia. Overcoming the inertia would require a project to run longer and a simultaneous knowledge-gathering effort, but PAR-L is a good starting point.
\end{abstract}

Keywords Participatory action research · Caribbean Netherlands · Invasive alien species · Latent environmental problems . Stakeholder involvement $\cdot$ Participatory governance

\section{Introduction}

The involvement of local communities in the management of the environment is by now widely accepted as crucial to successful governance (Armitage 2009; Folke et al. 2005; Lührs et al. 2018; Newig et al. 2018; Papadopoulos and Warin 2007; Turnhout et al. 2010). Approaches for doing so abound, and one that is increasingly applied is participatory action research (PAR), in which research into how to manage an environmental problem is fully co-created and co-conducted with members of the public (Shirk 2012). This goes beyond citizens participating in specific

Communicated by Chinwe Ifejika Speranza

Electronic supplementary material The online version of this article (https://doi.org/10.1007/s10113-020-01591-z) contains supplementary material, which is available to authorized users.

Jetske Vaas

j.vaas@uu.nl

Peter P. J. Driessen

p.driessen@uu.nl

Mendel Giezen

m.giezen@uva.nl

Frank van Laerhoven

F.S.J.vanLaerhoven@uu.nl research activities such as mapping (Hawthorne et al. 2015) or species monitoring (Dangles et al. 2010), as it involves locals in every step of the research. The knowledge created is used to inform action, with the aim of changing the day-to-day lives of a community (Kemmis et al. 2014a, b, Kindon et al. 2007, Reason and Bradbury 2001, Reason and Canney 2015). It has been quite successful in achieving improvements to livelihoods by ameliorating tangible environmental problems such as the depletion of fish stocks (Apgar et al. 2017a, b) or disputes about land-use (Valencia et al. 2012). PAR has fostered change by cocreating knowledge among stakeholders and researchers,

Martin J. Wassen

m.j.wassen@uu.nl

1 Copernicus Institute of Sustainable Development, Utrecht University, Utrecht, The Netherlands

2 Department of Human Geography, Planning, and International Development Studies, University of Amsterdam, Utrecht, The Netherlands 
strengthening social networks, opening up networks towards collaborative governance and generating compromises and shared visions (Apgar et al. 2017a, b; Trimble and Berkes 2013; Trimble and Lázaro 2014). Thus, PAR enables environmental problems to be addressed with the support and full involvement of a community. Nevertheless, there seems to be an absence of PAR studies of environmental management challenges with low impacts on people's livelihoods. We contend that there is a suite of environmental problems characterized by high uncertainty and a low threat to livelihoods, for which conventional PAR approaches are not suitable. These latent environmental problems result in community inertia, since the community does not clearly experience a problem, and this makes PAR's focus on shared visions and compromises inapplicable. Yet the full involvement of a community as fostered through PAR may still be required: for example, if their cooperation is needed to implement the solution. In this article, we therefore develop an alternative approach for conducting PAR, suitable for latent environmental problems. To that end, we first elaborate on latent environmental problems and the ensuing inertia, then outline the steps to conduct and lastly present criteria for evaluating such a trajectory. These three elements are demonstrated on a latent environmental problem in the Caribbean Netherlands: the invasive alien Coralita vine.

\section{Tailoring participatory action research to latent environmental problems}

Participatory action research can be conducted in many different ways, but we argue extant approaches for doing so to be less suitable for latent environmental problems. Here we elaborate on latent problems by presenting a typology based on the predictability and threat of impacts and on the inertia they result in. Then, we present a step-by-step guide and an evaluation framework for PAR pertaining to such cases.

\section{Latent problems and the inertia that ensues}

We first introduce a typology of environmental problems, to illustrate the types of problem for which we think the conventional PAR approaches are not applicable, centred on the impacts on a community's livelihoods and on the certainty these impacts will occur. Then, we look at how inertia may ensue, and why that poses an atypical challenge for PAR.

\section{A typology of environmental problems}

Several typologies have been developed to categorize environmental problems according to the type and degree of uncertainty involved. For example, De Boer et al. (2010) distinguish between uncertainty pertaining to cause and effect relations and uncertainty regarding preferred outcomes. Inspired by, among others, Hisschemöller and Hoppe (1995), Hurlbert and Gupta (2015) propose a grid in which one axis represents agreement on values and norms, and the other represents agreement about the science. Van Enst et al. (2014) use the same distinction but call the axes consensus on relevant norms and values and certainty of relevant knowledge. A general distinction we glean from these typologies is between uncertainties that are subjective (norms, values) and those that are objective (facts, science). Similarly, Gormley (1986) introduced the distinction between salience and complexity of issues, with salience defined as whether the public is interested in an issue. Building on the thinking about salience and normative aspects of environmental issues, we look at an issue's salience to communities, defined by the threat it poses to their livelihoods. This is placed on the horizontal axis in Fig. 1, juxtaposed against the predictability of an environmental problem's impact on the vertical axis. Predictability depends firstly on knowledge and understanding of the processes involved, i.e. the factors at play and their interactions such as feedbacks. Secondly, it depends on their
Fig. 1 Typology of environmental challenges, according to threats posed to livelihoods and the predictability of impacts

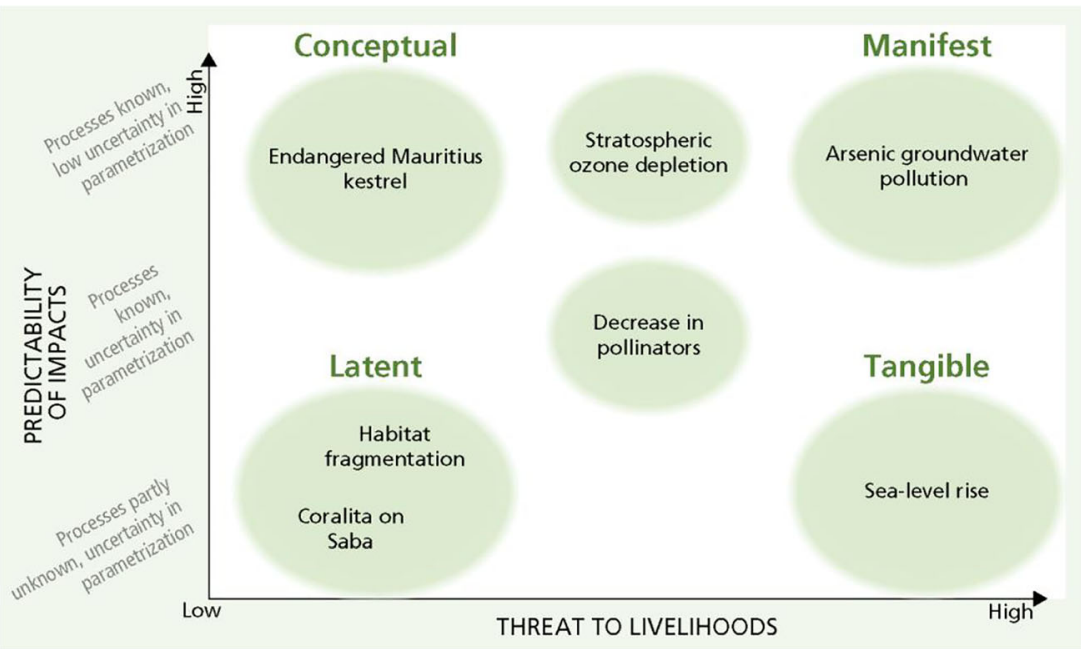


parametrization, i.e. the quantification of these impacts, which is a step further in uncertainty reduction and allows predictive models to be calibrated and validated. The greater the predictability of impacts, the easier it is to prevent or deal with them, but whether people are interested in making any efforts to achieve this also depends on the threat posed to their livelihoods. Naturally, the threat of an environmental problem can differ across livelihoods; we use this grid only for a generalized and tentative categorization of environmental problems.

An example of a manifest problem is arsenic contamination of groundwater. The sources of contamination are well understood, as are the impacts on people via drinking water and accumulation in the soil and crops. The locations of pollution are well-known, thus making the impacts very predictable (Rajmohan and Prathapar 2014). This is not the case for tangible problems such as sea-level rise, since apart from the generally accepted understanding that the increase in anthropogenic greenhouse gas emissions has accelerated sea-level rise, the exact processes are largely unknown. Generally, thermal expansion and the melting of glaciers and ice sheets are seen as resulting in global mean sea-level rise (Le Bars 2018), but the models are highly complex and thus contested (Sriver et al. 2018). Making projections of local levels beyond their capacity (Rasmussen et al. 2018). Conversely, for conceptual problems the impacts are highly predictable, but threats to livelihoods are minimal. An example is the nearextinction of the Mauritius kestrel (Falco punctatus). How predator pressure from invasive species such as mongoose and the spraying of DDT affect the population of kestrels, is well understood (Cassimally 2010), but the impact of the species' decline on Mauritians' livelihood is zero. Environmental problems with an equally low threat to livelihoods but compounded by the low predictability of their impacts are what we call latent problems. An example of this is the fragmentation of habitats, which is argued to have a wide array of impacts, such as species' extinction (Benchimol and Peres 2014), disturbance of pollination dynamics (Hadley and Betts 2012) and evolutionary adjustment in reproductive traits of plants (Jacquemyn et al. 2012). However, none of these impacts, let alone their cumulative effect on an ecosystem scale, is fully understood (Ewers and Didham 2006). Another example is the invasive alien Coralita vine (Antigonon leptopus) on Saba, whose spread and impacts are poorly understood and whose threats are mainly ecological. This case is more elaborately discussed in the 'Applying the latency-attuned participatory action research on Coralita on Saba' section, as we use it to demonstrate our adjustments to PAR.

These four quadrants should be understood as heuristic categories for which in reality many hybrids exist. Stratospheric ozone depletion is one such example: the chemical process is very straightforward, captured by a formula of ozone-depleting substances (hydrocarbons) after photodissociation in the stratosphere releases halogen atoms that break down ozone into oxygen. Both the amount of ozone-depleting substances and the size of the hole in the ozone layer are easily and closely monitored (Grundmann 2018; Lovelock 1977). While the potential health impacts are severe, the threat to livelihoods is lower than for sea-level rise or arsenic groundwater contamination. Similar in its threat to livelihoods, but with less predictable impacts, is the decline of pollinators. We know how important pollination is for crop production and have a reasonable understanding of the processes that result in pollinator decline. Pesticides and pathogens are infamous culprits, as is habitat decline. The exact impacts of rising temperatures due to climate change on populations are less wellknown, but the main barrier to full understanding of pollinator decline is a shortage of long-term and geographically spread data (Jarvis 2018; Rhodes 2018). Thus, the processes are wellknown, but parametrization is not yet feasible.

PAR generally focusses on manifest problems, implying conflicts that need to be resolved. For example, in the village of Cinquera in El Salvador, PAR addressed conflicting claims to land used for agriculture by former civil war combatants and the severely impoverished villagers (Valencia et al. 2012). In the Barotse Floodplain of Zambia, PAR addressed an aquatic agricultural system on which both fishermen and government depend for their income (Apgar et al. 2017a, b). In Uruguay, PAR addressed declining fish stocks in coastal areas, on which the local communities fully depend for their livelihood (Trimble and Berkes 2015). Through PAR, trust between stakeholders was enhanced, reflective dialogue among them promoted, shared visions developed and compromise reached (Apgar et al. 2017a, b; Trimble and Berkes 2013; Trimble and Lázaro 2014). But whereas manifest problems come with conflicting stakes that matter to a community, latent environmental problems are characterized by a community's inertia in dealing with them, as discussed in the next section.

\section{Community inertia}

The purpose of PAR is to resolve problems that affect people's day-to-day lives, by generating knowledge and informing action (Bradbury 2015; Kemmis et al. 2014a, b). Thus, PAR projects select the problem to focus on jointly with the community (Bacon et al. 2013). However, in the case of latency, the community does not really experience a problem and is inert because of the uncertainties and low impact of the phenomenon. Inertia occurs when, among other factors, the costs of acting are high and not acting becomes rational in the face of large uncertainties (Munck af Rosenschöld et al. 2014). Acting on e.g. habitat fragmentation would entail large costs for a community, such as changing their land-use and creating ecological corridors. Given the uncertainties involved and the lack of threat to their livelihoods, inertia on the part of a community is understandable. This differs from diametrically opposed opinions resulting in an impasse (sensu Biesbroek et al. 
2014) or gridlock (sensu Jones and Baumgartner 2012). Nor is it a non-decision, where a community knows that existing authorities, powers and values will keep them from addressing the issue (Bachrach and Baratz 1963). Rather, a community's inertia is similar to Munck af Rosenschöld et al.'s institutional inertia, which they employ to explain the lagging responses to climate change: "Institutional inertia refers to the "stickiness" (Pierson 2004, p. 8) of institutions, or to how they resist change.' (Munck af Rosenschöld et al. 2014, 640).

We conceptualize community inertia as resulting from an aggregate of a community's practices in which sticking points prevent change from happening. A community can refrain from acting for many reasons, such as lack of faith in others' cooperation (Niemiec et al. 2016), tension around responsibilities and obligations (Head and Atchison 2015) or differences in prioritization (Tauro et al. 2018). In this article, we focus on the practices in which Coralita is embedded on Saba. Practices are purposeful arrangements of people relating to sayings and doings, such as land-use or harvesting, and are a common unit of analysis in PAR (Kemmis et al. 2014a, b). While practices themselves are purposeful, they can have corollary effects on, for example, a latent problem. We use the sticking point typology as presented succinctly by Waylen et al. (2015) to analyse elements of practices that keep a community inert regarding a latent environmental problem. Sticking points are a type of legacy effect that explain resistance to change, or why only incremental change is achieved. The term is similar to 'lock-in', 'pathway' or 'gridlock', but leaves open in what way change is resisted. Waylen et al. (2015) distinguish three types of sticking points: (1) institutional, which are the (in)formal rules and norms arising from previous ways of working; (2) cognitive, arising from ways of framing and knowing; and (3) political, which are sticking points arising from extant power relations and interests. The aggregate of practices explains why an environmental problem manifests itself the way it does in a given community. Next to that, it is necessary to map the practices and sticking points from whichintentionally or otherwise - inertia regarding a latent problem ensues, so improvements can be envisioned and implemented with a community. These changes should mean improvements for the community, while also adjusting practices such that the latent problem is positively affected; below, we outline a stepwise approach for achieving this.

\section{Tailoring participatory action research to deal with latent problems}

The community inertia described above is the main challenge to be dealt with in the case of latent problems, instead of a manifest problem's contradicting stakes. Yet PAR's aim to co-produce a solution with a community can be argued to be preferable for manifest and latent problems alike because it increases the democratic value, because locals have important insights, or because compliance is likely higher among those who have been involved (Bulkeley and Mol 2003; Glucker et al. 2013; Koontz and Thomas 2006). Therefore, we propose an adjusted approach for conducting PAR, which we name 'PAR-L', with the L referring to the latent problems it is intended to address. The approach comprises a step-by-step guide to conducting PAR-L and an evaluation framework to reflect on its success.

\section{A step-by-step guide to latency-attuned participatory action research}

PAR-L's aim is to work together with a community to jointly develop improvements to that community's practices that both benefit their day-to-day lives and address the latent problem affected by these practices. We outline seven steps for doing so, which are based on the conventional approaches to PAR (such as Apgar et al. 2017a, b, Bacon et al. 2013, Ballard and Belsky 2010, Kemmis et al. 2014a, b, Shirk 2012, Trimble and Berkes 2013). In essence, five stages are gone through: defining the issue, planning, acting, observing and reflecting (as presented by Apgar et al. 2017a, b). The process is iterative, so in the reflection phase it can be decided to start a new cycle, or during project implementation it can be decided to return to an earlier phase. The shape PAR trajectories take is highly unpredictable, since they are coproduced with the local community. Thus, the research approach and implementation procedure are chosen in accordance with the project aim that is selected. PAR trajectories should respond to a community's needs and advancements in understanding (Coughlan and Coghlan 2002). They start with researchers becoming or being made aware of an issue at stake in a certain community, which prompts them to start PAR. The problem is defined together with stakeholders and it forms the basis for drawing up a plan for researching or critically assessing related practices (Bacon et al. 2013; Kemmis et al. 2014a, b; Trimble and Lázaro 2014). Then a project is implemented to solve the issue and, based on a joint evaluation of the improvements made, a new cycle can be started. These steps are listed in the left-hand column of Table 1 together with an indication of why they need to be adjusted for PAR-L; the results of the adjustments are shown in the right-hand column. In step 2, the researchers gather an overview of practices and sticking points, which as the project progresses, may be added to. In step 3, the researchers and community jointly envision improvements to these practices and sticking points that benefit the community's livelihoods while also positively affecting the latent environmental problem. These changes are then to be implemented in the subsequent steps, thereby overcoming the community inertia regarding the latent problem and concomitantly improving the community's livelihoods. In the last step, the changes are evaluated, using the framework presented in the next section. 
Table 1 Steps proposed for PAR-L based on adjustments made to conventional PAR approaches

\begin{tabular}{|c|c|c|c|}
\hline & PAR step & $\begin{array}{l}\text { Reason for } \\
\text { adjustments }\end{array}$ & Proposed PAR-L step \\
\hline 1 & $\begin{array}{l}\text { Researchers hear } \\
\text { about a problem a } \\
\text { community is } \\
\text { experiencing }\end{array}$ & $\begin{array}{l}\text { A latent problem } \\
\text { implies that a } \\
\text { community is not } \\
\text { experiencing a } \\
\text { problem }\end{array}$ & $\begin{array}{c}\text { Researchers approach } \\
\text { a community abou } \\
\text { a latent problem }\end{array}$ \\
\hline 2 & $\begin{array}{l}\text { The community's } \\
\text { practices } \\
\text { concerning that } \\
\text { problem are } \\
\text { explored }\end{array}$ & $\begin{array}{l}\text { The focus is on inertia } \\
\text { rather than a } \\
\text { problem, so we } \\
\text { should look for } \\
\text { sticking points } \\
\text { within the practices }\end{array}$ & $\begin{array}{l}\text { The community's } \\
\text { practices and } \\
\text { sticking points } \\
\text { adding to the } \\
\text { inertia regarding } \\
\text { the latent problem } \\
\text { are explored }\end{array}$ \\
\hline 3 & $\begin{array}{l}\text { A research aim is } \\
\text { formulated to } \\
\text { address the } \\
\text { problem }\end{array}$ & $\begin{array}{l}\text { Due to problem } \\
\text { perceptions being } \\
\text { latent, the } \\
\text { community will } \\
\text { not see a clear } \\
\text { research aim }\end{array}$ & $\begin{array}{l}\text { Possible } \\
\text { improvements to } \\
\text { the practices and } \\
\text { sticking points are } \\
\text { envisioned jointly } \\
\text { with the } \\
\text { community }\end{array}$ \\
\hline 4 & $\begin{array}{l}\text { A project is designed, } \\
\text { to attain the } \\
\text { research aim }\end{array}$ & $\begin{array}{l}\text { The focus is on the } \\
\text { improvements } \\
\text { envisioned with } \\
\text { the community }\end{array}$ & $\begin{array}{l}\text { A project is designed } \\
\text { in order to achieve } \\
\text { the improvements }\end{array}$ \\
\hline 5 & $\begin{array}{l}\text { The project is } \\
\text { implemented and } \\
\text { its implementation } \\
\text { is documented }\end{array}$ & $\begin{array}{l}\text { No adjustments } \\
\text { needed }\end{array}$ & $\begin{array}{l}\text { The project is } \\
\text { implemented and } \\
\text { its effects are } \\
\text { documented }\end{array}$ \\
\hline 6 & $\begin{array}{l}\text { The findings are } \\
\text { disseminated and } \\
\text { discussed }\end{array}$ & $\begin{array}{l}\text { No adjustments } \\
\text { needed }\end{array}$ & $\begin{array}{l}\text { The findings are } \\
\text { disseminated and } \\
\text { discussed }\end{array}$ \\
\hline 7 & $\begin{array}{l}\text { The project is } \\
\text { reflected on }\end{array}$ & $\begin{array}{l}\text { No adjustments } \\
\text { needed }\end{array}$ & $\begin{array}{l}\text { The project is } \\
\text { reflected on }\end{array}$ \\
\hline
\end{tabular}

\section{Evaluation scheme for the latency-attuned participatory action research}

A PAR-L trajectory aims at overcoming community inertia regarding a latent environmental problem by implementing changes co-developed with the community to practices and sticking points. These changes should both improve the community's livelihood and positively impact the latent problem. We adjusted two PAR evaluation schemes to fit the PAR-L aim presented by Trimble and Lázaro (2014) and Kraaijvanger et al. (2016). We added criteria regarding the upscaling potential of the project, the envisioning of an improved situation by participants, and understanding and overcoming the community inertia; this resulted in 15 evaluation criteria for a PAR-L trajectory. These criteria are listed and operationalized in Table 2, for application in the reflection in step 7, which informs the decision on how to proceed.

\section{Applying the latency-attuned participatory action research on Coralita on Saba}

Having elaborated on how to conduct and evaluate PAR-L, we now demonstrate its merit for application to a latent environmental problem, namely the invasive alien Coralita vine that covers large stretches of land on the island of Saba in the Caribbean Netherlands. Saba is the northernmost volcanic island in the active arc of the Lesser Antilles, with a terrestrial surface of $13 \mathrm{~km}^{2}$ and 2010 inhabitants in 2016 (CBS 2017; de Freitas et al. 2016). Saba has been part of the Caribbean Netherlands and a special municipality of the Netherlands since 2010. Hence, nature management responsibilities are held both by the ministries in The Hague and local Saba government (Vaas et al. 2017). But up until now there has been a lack of policy and of concerted control efforts, and there are no apparent stakeholder groups regarding Coralita (Vaas et al. 2017; Vaas et al. 2019). Ecologists claim Coralita poses an enormous risk to biodiversity, but understanding of the processes in play is largely lacking and there do not appear to be any threats to people's livelihoods (Jongman et al. 2010; Smith et al. 2014; Sweeney 2018). It has been documented that Coralita rapidly covers vast areas and is very tough to remove due to its tuberous roots (Burke and diTommaso 2011), which is why it is a threat to native flora and fauna, including the endangered iguana (van der Burg et al. 2012). Thus, the predictability of the vine's impacts is low. As is the threat it poses to livelihoods: it is a nuisance in yards, and locals generally dislike the vine (Vaas et al. 2017, Vaas et al. 2019). There are a few farmers on Saba, but the scale of agriculture is very limited (CBS 2017, Ministerie van BZK 2018). Thus, for the large majority of Sabans, Coralita poses no threat to their livelihoods, and there is little incentive to make the huge effort removal of the vine requires.

This is problematic, since invasive alien species (IAS) can have disastrous effects, especially on islands (Russell et al. 2017). Moreover, involvement of stakeholders is crucial, due to the need for full participation for successful management of IAS (Niemiec et al. 2016; Stokes et al. 2006; Verbrugge et al. 2013). Involvement of the Saban community is even more important because $90 \%$ of land is privately owned and there are no spatial planning ordinances (Schoenmaeckers 2010). Coralita on Saba is thus a good case of a latent problem for demonstrating the potential of PAR-L, and the small scale of the community makes it an expedient setting. While it means a lower absolute number of interviewees and participants, it also results in a highly representative sample: small numbers of participants do not preclude impact, as long as the participants are representative (see Ens et al. 2016). In the following, we recount the methods employed in the demonstration case. 
Table 2 Evaluation criteria for latency-attuned participatory action research

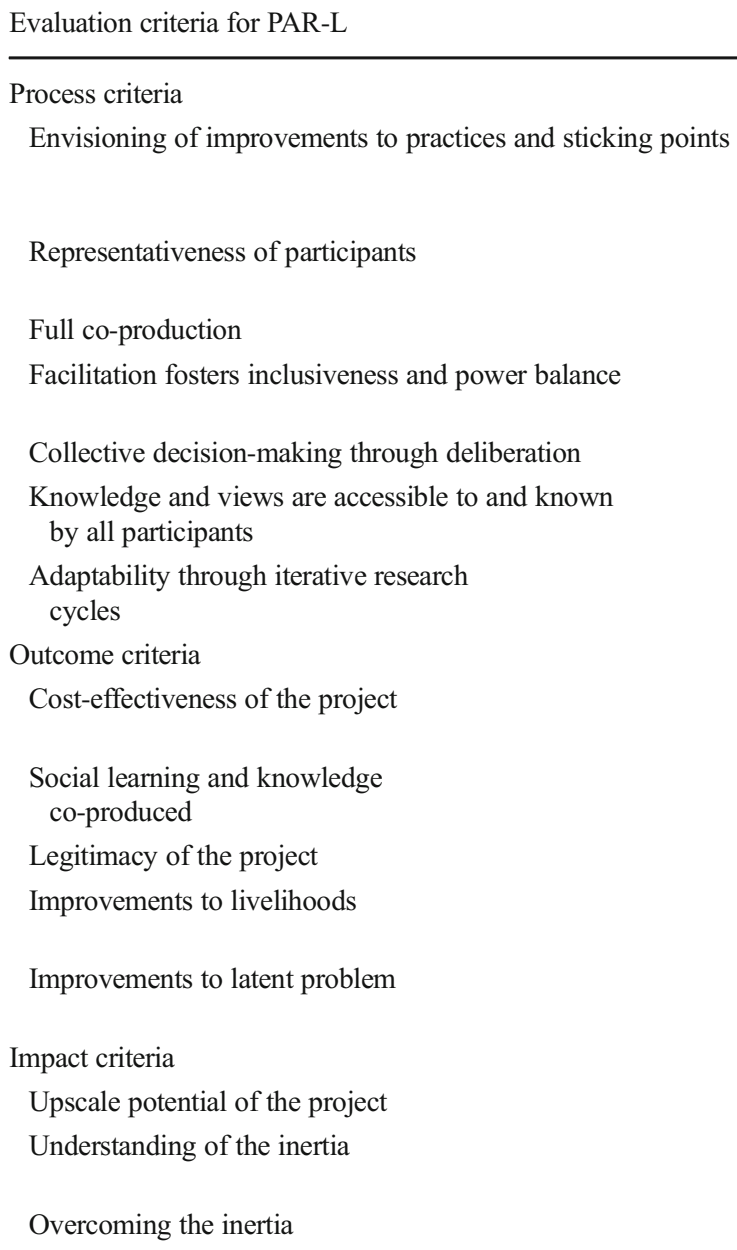

Operationalization

The participants were able to jointly envision changes to practices and sticking points that would improve their livelihoods and positively affect the latent problem.

Participants feel the breadth of local views was represented in the team.

Participants were involved in the entire PAR-L trajectory.

Participants feel their views were equally important and represented.

Participants feel decisions were made by them all, together.

Participants feel they were aware of everyone's views and knowledge, and of decisions made.

The project could be adapted while ongoing, or new cycles started.

The ratio of investments required from participants to the improvements they experienced.

Participants learned from each other and produced knowledge together.

Participants feel the project was legitimate.

Participants think the project has resulted in improving their day-to-day lives.

The researchers think the project positively affected the latent environmental problem.

Are there any possibilities and plans for upscaling the project?

Were the researchers able to identify the relevant practices and sticking points resulting in community inertia?

Were the researchers able to change anything about the community inertia?

\section{Methods used in this demonstration case}

Our trajectory, which ran from December 2017 to June 2018, employed different methods that were partially decided on in advance but mainly chosen during the process. In Table 3 a brief overview of activities per step and methods employed is given, and a detailed project description can be found in the Supplementary material.

\section{Guided tours}

During steps 2 and 4, we needed information that is only available to locals: for example, the boundaries of properties and the historic uses of land. Guided tours allow locals and researchers to exchange such information, which is not otherwise obtainable (Berbés-Blázquez 2011). Accompanied by one or several locals, the first author visited an area and discussed the boundaries, land-use, ownership disputes and visions for future developments. The tours generally lasted an hour. We used these tours to find a project area, and to make designs for a project.

\section{Interviews and focus groups}

Semi-structured interviews were conducted during steps 2, 5 and 7. In steps 2 and 5, the interviews served to explore practices and sticking points regarding Coralita. We complemented this data with insights from interviews conducted earlier (Vaas et al. 2017). During implementation of the project, step 5, we frequently met briefly with the core team to discuss progress. The interviews in step 7 served to evaluate the project, using the criteria in Table 2; we thought the privacy of an interview would elicit franker answers (see Table 1 in the Online resource for an overview). As well as interviews, we conducted focus group sessions with the core team assembled in step 3. These served for discussing and creating understanding of the views of others, for co-creating knowledge and collectively interpreting experiences (Cameron 2010; Ingram et al. 2015). Thus, two focus group 
Table 3 Activities and methods used per step of the demonstration case

Project step Method or tool applied

Step 1 The authors became aware of Coralita on Saba and started a PAR-L trajectory.

Step 2 The first author scouted areas covered in Coralita, where alternatives could be tried out, and asked Sabans to indicate areas where they are most weary of Coralita. The practices and sticking points at play regarding Coralita were elicited through interviews. A survey measured the experienced 'invincibility of Coralita'.

Step 3 A public evening was organized to envision improvements to practices and sticking points, where more local agriculture received much support. Hence, a project to replace Coralita with fruit trees was decided upon and a core team of seven Sabans was established.

Step 4 Jointly with the local government and some agriculture-practicing citizens, planting fruit trees on a Coralita-covered area in St. John's was decided upon by the core team.

Step 5 With help from local children, Coralita was removed from the project area. Five lemon trees were planted, which were watered and kept free from Coralita by one of the core team members.

Step 6 A public meeting and a closed meeting with the core team was held to discuss the experiences with the lemon trees. The core team members were surveyed again on the experienced 'invincibility of Coralita'.

Step 7 During the focus group of step 6 and interviews with the individual core Focus group, interviews team members, the project with the lemon trees, as well as the full PAR-L trajectory, was reflected upon.
This was described in the first two paragraphs of the 'Applying the latency-attuned participatory action research on Coralita on Saba' section.

Guided tours, interviews, PPGIS, survey

Focus group

Guided tours

Interviews and participant observation

Focus group, survey

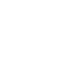
PAR

sessions were held; one during step 4 and one combining steps 6 and 7. The interviews and focus groups were audio recorded and transcribed, and analysed in NVivo 11.4.1. We coded according to a grounded theory approach, starting with open coding, followed by axial coding and, finally, closed coding (Kock 2004). Additionally, we coded deductively for the variables in Table 2, as well as for the practices and sticking points identified.

\section{Survey}

We administered a small-scale questionnaire on the perceived invincibility of Coralita; the set-up and results can be found in the Online resource. It was filled out by the core team members before and after the project (steps 2 and 6) and by a control group of 43 Sabans during step 2. This increased our understanding of the cognitive sticking point that Coralita is invincible and gave an indication of whether the PAR-L project changed that sticking point.

\section{Public participatory mapping}

During step 2, we employed public participatory GIS (PPGIS) to give some spatial context to the Coralita issue. PPGIS is used to gather information on individual or community experiences of ecosystem services, to research ecological and social values in tandem or to evaluate the compatibility of different projected uses of an area (Alessa et al. 2008, see Brown and Fagerholm 2015, Ramirez-Gomez et al. 2016). We used it to find out if there are areas where people are more annoyed by the vine. Fifty Sabans delineated up to five areas each, guided by the question 'Where do you not want Coralita?', regardless of whether the vine was already present or not. The drawing was done on a tablet using ESRI's ArcGis Collector App and the resulting drawings were collated in ArcMap; the result is shown in Fig. 2. Additionally, we undertook a small mapping exercise regarding fences and the presence of Coralita, to tentatively test a dynamic we observed. To that end, we walked one village and mapped all the intact fences and walls that could realistically be assumed to keep out goats. For each area, we indicated whether Coralita was present there; the result is presented in Figure 7 in the Online resource.

\section{Steps 1-6 of the demonstration case}

A detailed description of the full PAR-L trajectory on Saba can be found in the Online resource. Here we briefly discuss the main points, which are evaluated in the next section. We started with exploratory interviews to gauge interest in setting up a Coralita-related project and to explore practices affecting Coralita. Based on that analysis, a project in which Coralita was replaced with fruit trees was decided on with the core team, as we will explain after discussing the three main practices relating to goats, land-use and land titles, of which an overview is given in Fig. 3. 
Fig. 2 Where Coralita is unwanted on Saba, indicated by the pink areas. The brighter the pink, the more people (maximum of 17) indicated that area as preferably Coralita-free

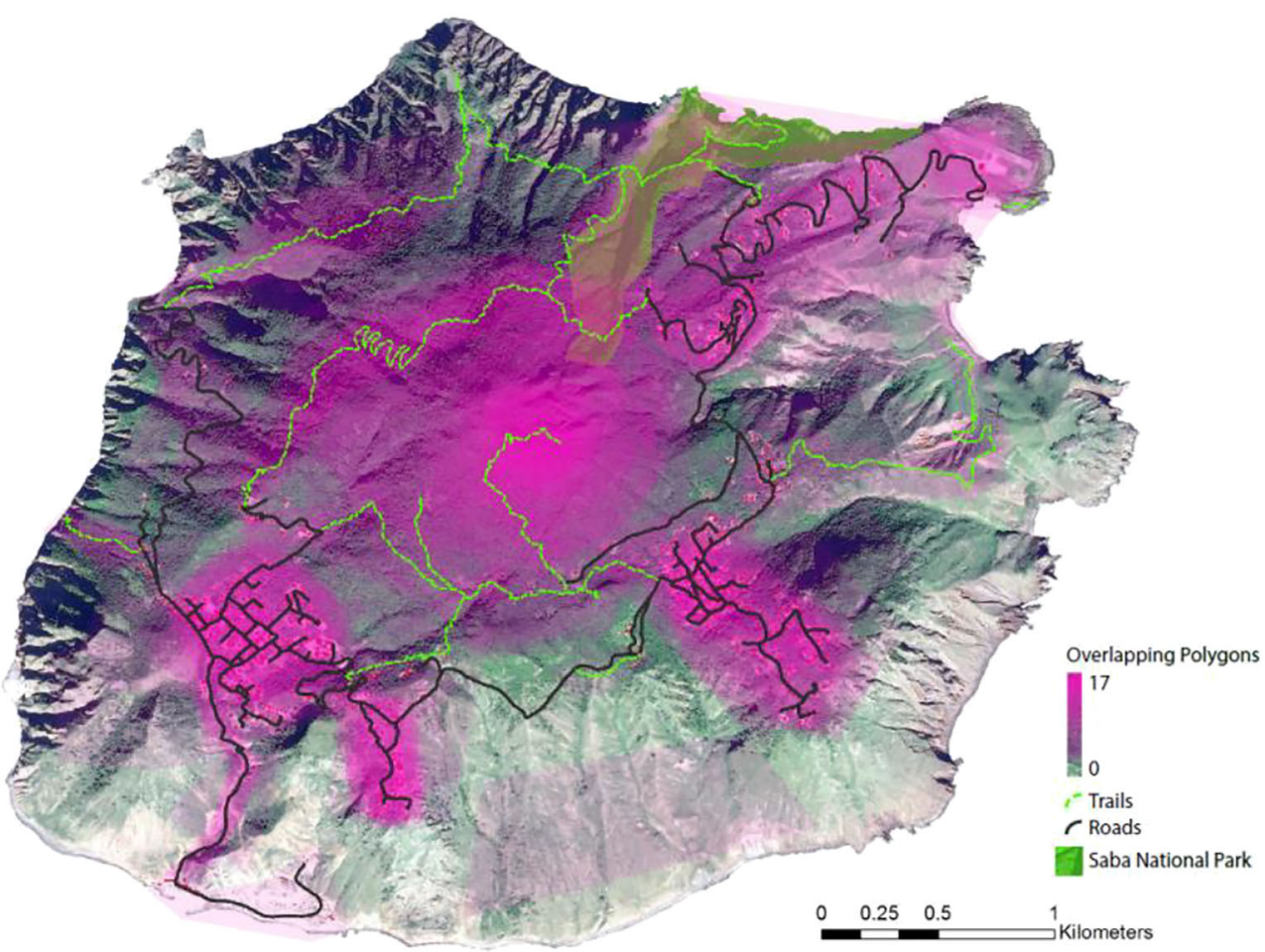

\section{Free-roaming goats}

Free-roaming goats are a persistent issue on Saba, despite the island ordinance that requires animals to be fenced in and tagged (Saba Government 2004). Two 'goat buy-back' programmes have been conducted on Saba and in each village a hunter holds a permit to shoot free-roaming goats (DCNA 2017, Ministerie van EZ 2017). Accounts of whether this actually happens are contradictory, but informants agree that even in the food-scarce period after the hurricanes of September 2017, no goats were eaten. This contradicts the argument from interviewees that goats are a standby for hard times. The damage these animals do to nature and gardens is, however, severe. One calculation suggests that each year $1.8 \%$ of the total area of healthy land becomes degraded habitat due to goats (van der Lely et al. 2014, 20). In our project area, a

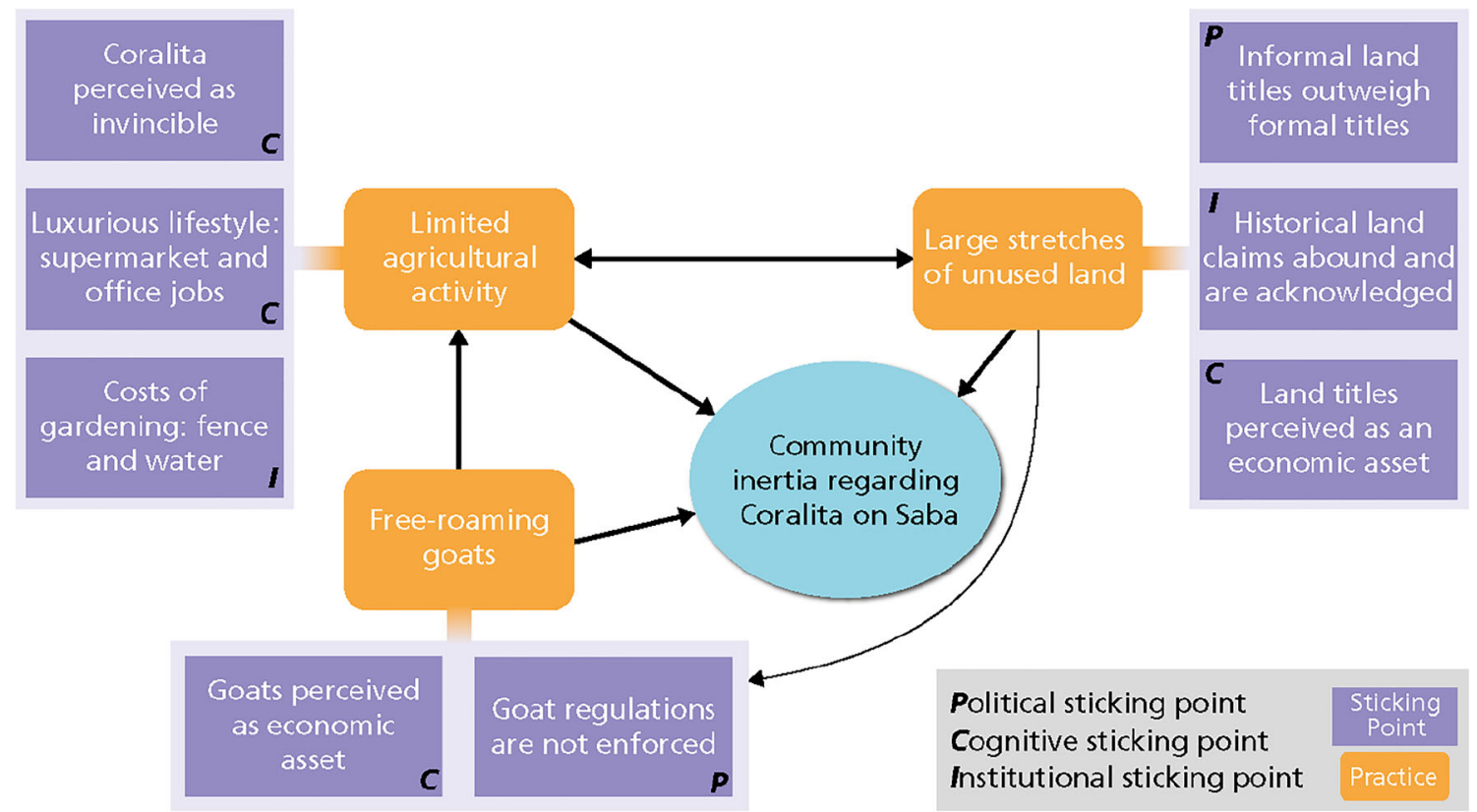

Fig. 3 Practices and sticking points that generate community inertia regarding Coralita on Saba 
fence was pushed over and one of the trees half-eaten. The offending goats are owned by the brother of a prominent politician and core team member, who in the evaluation interviews revealed the difficulty he had in getting his brother to comply with the island ordinance. Political stickiness is at play here: a political actor does not have the influence to confront goat owners. That the self-sufficiency from the past is invoked as a reason for keeping goats and that they are still regarded as a standby for hungry times together form a $c o g$ nitive sticking point. For Coralita management, properties will have to be fenced to keep out feral goats, resulting in a major cost to farmers, as we discuss in the next section.

\section{Limited agricultural activity}

The Saban government's Department of Agriculture provides farmers with free fencing and water tanks, and our project area received these resources too. However, only fulltime farmers are eligible, not people growing a few vegetables in their backyard. For these people, fences and water are costly and gardening is an expense rather than a profit, forming an institutional sticking point. The core team also pointed out the cognitive sticking point of the lack of appeal of agriculture: it is not a profession people aspire to anymore, and not having to work the land but buying food in a grocery store is considered a luxurious lifestyle. The core team member looking after the lemon trees was retired and farming on a small scale. Due to these two sticking points, most people consider the efforts and expenses required for transforming large stretches of Coralita land to be too high. And indeed, gardens with an intact fence are Coralita-free (see Figure 7 of the Online resource), since the people concerned have plans for their garden that warrant the expense. For them, Coralita is more of a tangible problem than a latent problem. A cognitive sticking point is Coralita widely being regarded as invincible, which adds to people's reluctance to garden. We conducted a survey among the core team to quantify this sticking point and gauge whether the PAR-L trajectory changed anything. The findings, discussed in Table 4, showed that people became more convinced not only of the vine's invincibility but also of the need to control it. One core team member also pointed out different views of what a yard should look like: land overgrown by a weed is not problematic to everyone. In addition, land titles are often an impediment to using land, as we discuss in the next section.

\section{Large stretches of unused land}

The property rights of one of the possible project areas were contested, which is a common phenomenon on Saba. Many properties are not officially registered in the cadastre, but vernacular knowledge on which family owns which area is widespread. In the past, land titles were not always registered correctly, and incomplete records of inhabitants make it impossible to reconstruct ownership properly (Franklin 2015). When the original owner died, the heirs were generally not registered as the new proprietors, resulting in a phenomenon known as 'undivided property' (de Kort 2009). In day-to-day reality, the informal ownership is respected by government institutions as if it were legal (Hof van Justitie 2018). Difficulties arise, however, when contradicting claims to land are made, and legally unsound deed transfers make it hard to adjudicate such conflicts. According to Dutch law, land on Saba for which the titles and deeds are not in order belongs to the island government. However, this is rarely enforced and the government does not engage in any type of spatial planning (Hof van Justitie 2018). This is an institutional sticking point: historical claims to land are informal rules abided by in the present, compounded by a political sticking point, of political actors not wanting to change that practice for fear of voters' backlash. Core team members confirmed the delicate nature of land titles and gave examples of how this practice hampers the establishment of nature areas, or the practising of agriculture. Lastly, they mentioned a cognitive sticking point: land is considered an asset and an investment for the future that does not need to be put to use at this moment. These areas provide space for the goats to roam, where they find their food and Coralita can spread freely, which makes agriculture even less attractive Fig. 3.

Together, the free-roaming goats, unused land and limited agricultural activity result in large stretches of unused land where Coralita is free to grow and increase its potential to spread. Sticking points such as a lack of law enforcement, historical land claims and costs of fencing make the community inert regarding this phenomenon. We selected the town of St. John's as our project area, based on a map of the areas where people do not want Coralita (see Fig. 2), the presence of Coralita and the availability of a project plot. At a public brainstorming evening, the participants were mainly interested in enhancing agriculture so as to achieve cheaper and betterquality food - an approach which would also help reduce the Coralita. A core team of seven was established, and jointly with the first author, they envisioned a fruit orchard as an attractive alternative for a Coralita-infested plot. Using input from them, the Department of Agriculture and local farmers, a design was made for an area made available by a member of the core team. Students in an after-school care programme mowed the Coralita in an attempt to eradicate it from the area, and the Department of Agriculture assisted with the planting and fencing-off of five lemon trees. The fences were reinforced once, but despite this, one was pushed over and a tree was half-eaten. The trees were watered daily by one of the core team members, using water from a cistern on the land, which was filled by the government. Two weeks after planting, Coralita had already appeared next to the lemon trees. It was removed by the first author and thereafter was only 
Table 4 Evaluation of the Saba demonstration case

Evaluation criteria for PAR-L

Process criteria

Envisioning improvements to practices and sticking points

Representativeness of participants

Full co-production

Facilitation fosters inclusiveness and power balance

Collective decision-making through deliberation

Knowledge and views are accessible to and known by all participants

Adaptability through iterative research cycles

Outcome criteria

Cost-effectiveness of the project

Social learning and knowledge co-produced

Legitimacy of the project

Improvements to livelihoods

Improvements to latent problem

Impact criteria

Upscale potential of the project

Understanding of the inertia
Results in the Saba demonstration case

The brainstorming evening attracted a good number of attendees, who jointly formulated a vision for a better situation regarding PAR and decided on a pilot project.

Participants stressed the difficulty of starting a social movement on Saba, and we did indeed invest much time in approaching people personally to get them involved. Participants were content about the actors involved, one explicitly praising the amount of local Sabans involved. Another stated several times that bringing a community together like this sets a good example. Youth and people living directly around the project area were mentioned as persons who could have been involved more.

Core team members were involved in every step, but in step 5 only one of them provided regular support. Interviewees indicated they had not only enjoyed the process but also admitted to being less active than they had planned to. They indicated that the facilitator could have given them more tasks.

One participant commented on this, asserting that the research team approaching potential participants personally and spending much time talking with them fostered their involvement and willingness to participate.

Two participants indicated that the course of the trajectory had not been decided by them; the others seemed neutral about this element.

Participants indicated they felt they had been kept up to date well.

Adaptions were made during the project: for example, deciding very early to go ahead with one area, given the high costs of fencing for the other area. The planting design was adjusted according to plans for a playground. The availability of plants on the island guided the decision about what to plant, and the costs of fencing resulted in the planting of a few trees and no larger areas with vegetables, etc. But no iteration took place.

A one-off investment of 150 USD and $8 \mathrm{~h}$ was made, for which we provide a breakdown in the Supplementary material. This gave us a good idea of the potential for upscaling the pilot; as the interviewees did not make any negative statements about the costs involved, this project was cost-effective. However, these costs were mentioned as a limiting factor for upscaling the project.

Participants mentioned two topics from which they learned. One related to organizing a project like this: one participant explicitly stated that much patience is required. Also mentioned was the challenge of getting Sabans together and jointly addressing an issue. The second topic mentioned was learning a bit about Coralita and how it can be managed by investing some effort. Also, every participant mentioned meeting new people or speaking properly with people they had previously only known by sight. One interviewee was especially happy about working with so many locals.

All participants were used to outsiders starting projects on Saba, and all locals indicated that they saw this as an opportunity for both parties to benefit. One expressed disappointment that no Sabans were setting this up and felt a chance was being missed by the Saban community.

Half the core team members were explicitly enthusiastic about the attention drawn to agriculture due to the project; the others were mostly concerned with how to continue the project. They stressed the limitation of time as a resource and the lack of the project's importance for Sabans.

Coralita was kept away from the trees, which means that on a very small scale some impact was had on the spread of the vine. As for the impact on Coralita, most of the core team members therefore felt this pilot made little difference. One member stressed that at least the area at the base of each tree had been kept Coralita-free and when scaled up that could be a significant area.

There is definitely potential for upscaling, since the core team felt Sabans should start more of these pilots. However, there were no concrete plans.

The authors obtained a very thorough understanding of the practices and sticking points resulting in community inertia regarding Coralita, as discussed in the 'Steps $1-6$ of the demonstration case' section. Experiencing some of them (e.g. dislike of agriculture, contested land titles) elicited topics to explore further, such as the land rights issue, which plays a much larger role than initially expected. Moreover, this topic appears to be only indirectly related to Coralita so may never have surfaced in interviews. In addition, links between elements and how they reinforce each other became clear. For example, the goats make fencing necessary, but fencing is very expensive, which in turn enhances the lack of land-use. Also important is the confidence generated by engaging in a project together with community members. We believe that in a conventional interview setting it 
Table 4 (continued)

Evaluation criteria for PAR-L

Overcoming the inertia
Results in the Saba demonstration case

would have been less likely for the politician to divulge disagreement with a family member or for a core team member to point out weaknesses of the community to an outsider.

The survey on the cognitive sticking point of invincibility of Coralita revealed some small changes between scores before and after the project (see Supplementary materials). For example, post-project all core team members disagreed with the statement 'If you have Coralita in your yard, it's impossible to remove', whereas pre-project half of them agreed. Before the project, half the respondents were undecided about the statement 'Saba is incapable of dealing with Coralita'; after the project, half agreed and half disagreed. The same undecidedness existed pre-project for the statement 'I do not have a good reason to remove Coralita from my land' but had also disappeared post-project. This survey is very small scale and tentative, but the moderately positive results were confirmed in evaluation interviews with the core team. Although the number of participants was not very large, the interviewees thought it was a good score by Saba standards. In addition, they saw an important contribution in attracting attention to agriculture and land-use. The pilot adjusted these practices on the scale of our small plot, but it did not engender a breakthrough on a larger scale. Had the PAR-L project run longer, larger-scale changes might have been achieved if more plots and people had been involved. removed from inside the fences by the core team member watering the trees. During another public evening, the end of May, the experiences with the lemon trees were discussed, such as the restraints posed by the need for water and the costs of fencing. Ideas were raised for follow-up research into removal methods and the exact impacts of the vine, as well as arrangements to fund larger-scale land conversion. Due to time and resource constraints, these ideas could not be put into practice in a new PAR-L cycle. Interviews with the core team members were conducted as well, to evaluate the trajectory; the results are presented in the next section.

\section{Step 7 of the demonstration case: reflection and evaluation}

The evaluation of the demonstration case is presented in Table 4. Three aspects stand out: (1) ownership of the project was rather low, which does not fit the co-production character of PAR projects; (2) adjustments were made during the project, but no new cycles were started; and (3) participants were positively surprised by the involvement of locals with the project. In the 'Conclusion and discussion' section, we reflect on the project's overall impact.

\section{Conclusion and discussion}

We started this article by pointing out a limitation of conventional PAR approaches when it comes to dealing with latent environmental problems, since it is centred around a community's wish to improve their day-to-day lives. We therefore developed an alternative approach (PAR-L), comprising a step-by-step guide and an evaluation framework. Within the demonstration case, both worked well, and some improvements could be made. Analysing sticking points and practices as a second step was useful, but the graphic depiction may suggest a degree of organization that does not exist in reality: the costs of gardening affect both agricultural and goat-related practices, and of course affect each another too. And the last two steps happened simultaneously, as it is hard to separate them. When working with the evaluation framework, we found that 'legitimacy of the project' was a rather abstract variable for participants to evaluate. Some of the variables, such as 'improvements to livelihoods' or 'overcoming the inertia' require a longer evaluation period to assess properly.

Overall, getting a community involved with a latent problem through addressing practices they would like to see improved, worked quite well. We identified and implemented adjustments that were beneficial both to the latent problem and to the community's livelihood, but only at project scale and during the project's duration. To have island-wide effects, multiple plots and a longer project period are needed. However, we foresee challenges to upscaling this project, due to what Mills et al. (2017) refer to as 'response efficacy': feeling that your behaviour will have the intended effect. While this is frequently mentioned as a factor limiting the implementation of policy or adoption of measures (e.g. Keshavarz and Karami 2016), it may also play a role before implementation, when involvement of a community or stakeholders is sought after to decide on what measures or policy to implement. Participants wanted to see the land-use practice changed but wondered whether this project would be able to do so. This goes to show that the latency of Coralita is not the only reason for the community inertia, and other factors such as project efficacy should be addressed in future PAR-L projects as well.

Related to project efficacy, questions regarding Coralita's impact and solutions to its invasion kept resurfacing: thus, the latency we tried to work around through PAR-L did not fully 
disappear from view. Looking back at the grid presented in Fig. 1, PAR-L worked mainly to achieve movement along the horizontal axis, by having the community identify points for improvements to practices to benefit their livelihoods. The project addressed a problem that matters to them, namely the lack of agriculture, and by doing so positively affected the latent problem of Coralita invasion. A simultaneous effort to move up the vertical axis should be made too; to achieve this, the literature on, for example, joint knowledge production (Hegger et al. 2012) and socially robust science (Seijger et al. 2016) might be useful in offering analytical and methodological tools for knowledge production that take account of stakeholders' questions, knowledge and interests. PAR-L's focus on improving day-to-day lives could thus be complemented with a knowledge-gathering component, preempting the risk that a low sense of project efficacy will keep the community from participating. With these improvements, we think our PAR-L approach is well equipped for overcoming a community's inertia regarding other latent environmental problems such as habitat fragmentation. Whether it would also work for non-latency incited inertia cannot be established based on this one case, but it is definitely suitable for cocreating solutions to problems that communities did not know they had.

Acknowledgements We thank the reviewers for their remarks that improved this article. The research was funded through the Netherlands Organisation for Scientific Research (NWO) Caribbean programme. J. Burrough advised on the English of a draft version of the manuscript. We are highly indebted to the participants for their time and effort put into this project, which we hope is to their benefit. Also, we thank the Caribbean Netherlands Science Institute, Dutch Caribbean Nature Alliance and Saba government for providing us support in our research. Lastly, the PPGIS was designed and conducted jointly with Elizabeth Haber, whose contribution we very much appreciate.

Open Access This article is licensed under a Creative Commons Attribution 4.0 International License, which permits use, sharing, adaptation, distribution and reproduction in any medium or format, as long as you give appropriate credit to the original author(s) and the source, provide a link to the Creative Commons licence, and indicate if changes were made. The images or other third party material in this article are included in the article's Creative Commons licence, unless indicated otherwise in a credit line to the material. If material is not included in the article's Creative Commons licence and your intended use is not permitted by statutory regulation or exceeds the permitted use, you will need to obtain permission directly from the copyright holder. To view a copy of this licence, visit http://creativecommons.org/licenses/by/4.0/.

\section{References}

Alessa L, Kliskey A, Brown G (2008) Social-ecological hotspots mapping: a spatial approach for identifying coupled social-ecological space. Landscape Urban Plann. https://doi.org/10.1016/j. landurbplan.2007.09.007
Apgar JM, Allen W, Albert J, Douthwaite B, Paz Ybarnegaray R, Lunda J (2017a) Getting beneath the surface in program planning, monitoring and evaluation: learning from use of participatory action research and theory of change in the CGIAR Research Program on Aquatic Agricultural Systems. Action Res. https://doi.org/10.1177/ 1476750316673879

Apgar JM, Cohen PJ, Ratner BD, de Silva S, Buisson M, Longley C, Bastakoti RC, Mapedza E (2017b) Identifying opportunities to improve governance of aquatic agricultural systems through participatory action research. Ecol Soc. https://doi.org/10.5751/ES-08929-220109

Armitage DR (2009) Adaptive co-management for social-ecological complexity. Front Ecol Environ. https://doi.org/10.1890/070089

Bachrach P, Baratz MS (1963) Decisions and nondecisions: an analytical framework. Am Polit Sci Rev. https://doi.org/10.2307/1952568

Bacon C, Devuono-Powell S, Frampton ML, Lopresti T, Pannu C (2013) Introduction to empowered partnerships: community-based participatory action research for environmental justice. Environ Justice. https://doi.org/10.1089/env.2012.0019

Ballard HL, Belsky JM (2010) Participatory action research and environmental learning: implications for resilient forests and communities. Environ Educ Res. https://doi.org/10.1080/13504622.2010.505440

Benchimol M, Peres CA (2014) Predicting primate local extinctions within "real-world" forest fragments: a pan-neotropical analysis. Am J Primatol. https://doi.org/10.1002/ajp.22233

Berbés-Blázquez M (2011) A participatory assessment of ecosystem services and human wellbeing in rural Costa Rica using photo-voice. Environ Manag 49:862-875. https://doi.org/10.1007/s00267-012-9822-9

Biesbroek GR, Termeer CJAM, Klostermann JEM, Kabat P (2014) Rethinking barriers to adaptation: mechanism-based explanation of impasses in the governance of an innovative adaptation measure. Glob Environ Chang. https://doi.org/10.1016/j.gloenvcha.2014.04.004

Bradbury H (2015) The SAGE handbook of action research

Brown G, Fagerholm N (2015) Empirical PPGIS/PGIS mapping of ecosystem services: a review and evaluation. Ecosystem Services. https://doi.org/10.1016/j.ecoser.2014.10.007

Bulkeley H, Mol APJ (2003) Participation and environmental governance: consensus, ambivalence and debate. Environ Values. https://doi.org/10.3197/096327103129341261

Burke JM, diTommaso A (2011) Corallita (Antigonon leptopus): intentional introduction of a plant with documented invasive capability. Invasive Plant Sci Manage. https://doi.org/10.1614/IPSM-D-10-00088.1

Cameron J (2010) Focusing on the focus group. In: Hay I (ed) Qualitative research methods in human geography, 3rd edn. Oxford University Press, pp 152-172

Cassimally KA (2010) Mauritius kestrel: a conservation success story. Sci Am

CBS (2017) Trends in the Caribbean Netherlands 2017

Coughlan P, Coghlan D (2002) Action research for operations management. Int J Oper Prod Manag. https://doi.org/10.1108/ 01443570210417515

Dangles O, Carpio FC, Villares M, Yumisaca F, Liger B, Rebaudo F, Silvain JF (2010) Community-based participatory research helps farmers and scientists to manage invasive pests in the Ecuadorian Andes. AMBIO 39:325-335

DCNA (2017) Goat buy back project. BioNews:6-7

de Boer J, Wardekker JA, van der Sluijs JP (2010) Frame-based guide to situated decision-making on climate change. Glob Environ Chang. https://doi.org/10.1016/j.gloenvcha.2010.03.003

de Freitas JA, Rojer AC, Nijhof BSJ, Debrot AO (2016) A landscape ecological vegetation map of Saba (Lesser Antilles) C195/15:1-48

de Kort PE (2009) Langdurig onverdeeld gebleven boedels in de Nederlandse Antillen. Weekblad voor privaatrecht, notariaat en registratie 646:81-103

Ens EJ, Daniels C, Nelson E, Roy J, Dixon P (2016) Creating multifunctional landscapes: using exclusion fences to frame feral ungulate management preferences in remote Aboriginal-owned northern Australia. Biol Conserv. https://doi.org/10.1016/j.biocon.2016.03.007 
Ewers RM, Didham RK (2006) Confounding factors in the detection of species responses to habitat fragmentation. Biol Rev Camb Philos Soc. https://doi.org/10.1017/S1464793105006949

Folke C, Hahn T, Olsson P, Norberg J (2005) Adaptive governance of social-ecological systems. Annu Rev Environ Resour. https://doi. org/10.1146/annurev.energy.30.050504.144511

Franklin LA (2015) De wettelijke vereffening volgens het nieuwe erfrecht: een oplossing voor onbewoonde huizen in Curaçao? Dissertation or Thesis, University of Curaçao Dr. Moises Frumencio da Costa Gomez

Glucker AN, Driessen PPJ, Kolhoff A, Runhaar HAC (2013) Public participation in environmental impact assessment: why, who and how? Environ Impact Assess Rev. https://doi.org/10.1016/j.eiar. 2013.06.003

Gormley WTJ (1986) Issue networks in a federal system. Polity 18:595-620

Grundmann R (2018) Ozone and climate governance: an implausible path dependence. Compt Rendus Geosci. https://doi.org/10.1016/j.crte. 2018.07.008

Hadley AS, Betts MG (2012) The effects of landscape fragmentation on pollination dynamics: absence of evidence not evidence of absence. Biol Rev. https://doi.org/10.1111/j.1469-185X.2011.00205.x

Hawthorne TL, Elmore V, Strong A, Bennett-Martin P, Finnie J, Parkman J, Harris T, Singh J, Edwards L, Reed J (2015) Mapping non-native invasive species and accessibility in an urban forest: a case study of participatory mapping and citizen science in Atlanta. Georgia Appl Geogr doi. https://doi.org/10.1016/j.apgeog.2014.10.005

Head L, Atchison J (2015) Governing invasive plants: policy and practice in managing the Gamba grass (Andropogon gayanus) - bushfire nexus in northern Australia. Land Use Policy. https://doi.org/10. 1016/j.landusepol.2015.04.009

Hegger D, Lamers M, Van Zeijl-Rozema A, Dieperink C (2012) Conceptualising joint knowledge production in regional climate change adaptation projects: success conditions and levers for action. Environ Sci Pol. https://doi.org/10.1016/j.envsci.2012.01.002

Hisschemöller M, Hoppe R (1995) Coping with intractable controversies: the case for problem structuring in policy design and analysis. Know Techn Pol. https://doi.org/10.1007/BF02832229

Hurlbert M, Gupta J (2015) The split ladder of participation: a diagnostic, strategic, and evaluation tool to assess when participation is necessary. Environ Sci Pol. https://doi.org/10.1016/j.envsci.2015.01.011

Ingram M, Murrietta L, de Zapien JG, Herman PM, Carvajal SC (2015) Community health workers as focus group facilitators: a participatory action research method to improve behavioral health services for farmworkers in a primary care setting. Action Res. https://doi. org/10.1177/1476750314565913

Jacquemyn H, de Meester L, Jongejans E, Honnay O (2012) Evolutionary changes in plant reproductive traits following habitat fragmentation and their consequences for population fitness. J Ecol. https://doi.org/ 10.1111/j.1365-2745.2011.01919.x

Jarvis B (2018) The insect apocalypse is here. What does it mean for the rest of life on earth?. The New York Times Magazine

Jones BD, Baumgartner FR (2012) From there to here: punctuated equilibrium to the general punctuation thesis to a theory of government information processing. Policy Stud J. https://doi.org/10.1111/j. 1541-0072.2011.00431.x

Jongman RHG, Meesters HWG, Debrot AO (2010) Biodiversiteit voor de BES-eilanden; Bonaire, St. Eustatius en Saba. Onderzoeksvragen en verplichtingen Alterra-report 2080; IMARES-report C117/10

Kemmis S, Nixon R, McTaggart R (2014a) The action research planner. Doing critical participatory action research. Springer, Singapore

Kemmis S, Wilkinson J, Edwards-Groves C, Hardy I, Grootenboer P, Bristol L (2014b) Changing practices, changing education. Springer, Singapore

Keshavarz M, Karami E (2016) Farmers' pro-environmental behavior under drought: application of protection motivation theory. J Arid Environ. https://doi.org/10.1016/j.jaridenv.2015.11.010
Kindon S, Pain R, Kesby M (2007) Participatory action research approaches and methods. Routledge, London

Kock N (2004) The three threats of action research: a discussion of methodological antidotes in the context of an information systems study. Decis Support Syst. https://doi.org/10.1016/S0167-9236(03)00022-8

Koontz TM, Thomas CW (2006) What do we know and need to know about the environmental outcomes of collaborative management? Public Adm Rev. https://doi.org/10.1111/j.1540-6210.2006.00671.x

Kraaijvanger R, Veldkamp T, Almekinders C (2016) Considering change: evaluating four years of participatory experimentation with farmers in Tigray (Ethiopia) highlighting both functional and human-social aspects. Agric Syst. https://doi.org/10.1016/j.agsy.2016.05.001

Le Bars D (2018) Uncertainty in sea level rise projections due to the dependence between contributors. Earth's Futur. https://doi.org/10. 1029/2018EF000849

Lovelock JE (1977) Halogenated hydrocarbons in the atmosphere. Ecotoxicol Environ Saf. https://doi.org/10.1016/0147-6513(77) 90030-6

Lührs N, Jager NW, Challies E, Newig J (2018) How participatory should environmental governance be? Testing the applicability of the Vroom-Yetton-Jago model in public environmental decision-making. Environ Manage. doi: https://doi.org/10.1007/s00267-0170984-3, 61, 249, 262

Mills J, Gaskell P, Ingram J, Dwyer J, Reed M, Short C (2017) Engaging farmers in environmental management through a better understanding of behaviour. Agric Hum Values 34:283-299. https://doi.org/10. 1007/s10460-016-9705-4

Munck af Rosenschöld J, Rozema JG, Frye-Levine LA (2014) Institutional inertia and climate change: a review of the new institutionalist literature. Wiley Interdiscip Rev Clim Chang. https://doi. org/10.1002/wcc. 292

Newig J, Challies E, Jager NW, Kochskaemper E, Adzersen A (2018) The environmental performance of participatory and collaborative governance: a framework of causal mechanisms. Policy Stud J. https://doi.org/10.1111/psj.12209

Niemiec RM, Ardoin NM, Wharton CB, Asner GP (2016) Motivating residents to combat invasive species on private lands: social norms and community reciprocity. Ecol Soc. https://doi.org/10.5751/ES08362-210230

Papadopoulos Y, Warin P (2007) Are innovative, participatory and deliberative procedures in policy making democratic and effective? Eur J Polit Res. https://doi.org/10.1111/j.1475-6765.2007.00696.x

Rajmohan N, Prathapar SA (2014) Extent of arsenic contamination and its impact on the food chain and human health in the Eastern Ganges Basin: a review. IWMI Work Pap. https://doi.org/10.5337/2014.224

Ramirez-Gomez SOI, Brown G, Verweij PA, Boot R (2016) Participatory mapping to identify indigenous community use zones: implications for conservation planning in southern Suriname. J Nat Conserv. https://doi.org/10.1016/j.jnc.2015.11.004

Rasmussen DJ, Bittermann K, Buchanan MK, Kulp S, Strauss BH, Kopp RE, Oppenheimer M (2018) Extreme sea level implications of 1.5 ${ }^{\circ} \mathrm{C}, 2.0^{\circ} \mathrm{C}$, and $2.5^{\circ} \mathrm{C}$ temperature stabilization targets in the $21 \mathrm{st}$ and 22nd centuries. Environ Res Lett. https://doi.org/10.1088/17489326/aaac87

Reason P, Bradbury H (2001) Handbook of action research. Participative inquiry and practice. SAGE, London

Reason P, Canney S (2015) Action research and ecological practice. In: Bradbury $\mathrm{H}$ (ed) The SAGE handbook of action research. SAGE Publications

Rhodes CJ (2018) Pollinator decline - an ecological calamity in the making? Sci Prog. https://doi.org/10.3184/003685018X15202512854527

Russell JC, Meyer J, Holmes ND, Pagad S (2017) Invasive alien species on islands: impacts, distribution, interactions and management. Environ Conserv. https://doi.org/10.1017/S0376892917000297

Saba Government (2004) Identification and Registration of Livestock and Domestic Animals Ordinance AB2004 
Schoenmaeckers B (2010) Saba, the unspoiled queen. Change Magazine 6:36-39

Seijger C, Otter HS, van Tatenhove J, Dewulf G (2016) Socially robust knowledge in coastal projects. Environ Sci Pol. https://doi.org/10. 1016/j.envsci.2015.03.004

Shirk JL (2012) Public participation in scientific research: a framework for deliberate design. Ecol Soc. https://doi.org/10.5751/ES-04705170229

Smith SR, van der Burg WJ, Debrot AO, van Buurt G, de Freitas JA (2014) Key elements towards a joint invasive alien species strategy for the Dutch Caribbean IMARES C020/14 - PRI report number 550:1-102

Sriver RL, Lempert RJ, Wikman-Svahn P, Keller K (2018) Characterizing uncertain sea-level rise projections to support investment decisions. PLoS One. https://doi.org/10.1371/journal.pone. 0190641

Stokes KE, O'Neill KP, Montgomery WI, Dick JTA, Maggs CA, Mcdonald RA (2006) The importance of stakeholder engagement in invasive species management: a cross-jurisdictional perspective in Ireland. Biodivers Conserv. https://doi.org/10.1007/s10531-005$3137-6$

Sweeney L (2018) Assessing the impact of Antigonon leptopus on Saba and St. Eustatius. Dissertation or Thesis

Tauro A, Gómez-Baggethun E, García-Frapolli E, Chavero EL, Balvanera P (2018) Unraveling heterogeneity in the importance of ecosystem services: individual views of smallholders. Ecol Soc. https://doi.org/10.5751/ES-10457-230411

Trimble M, Berkes F (2013) Participatory research towards co-management: lessons from artisanal fisheries in coastal Uruguay. J Environ Manag. https://doi.org/10.1016/j.jenvman.2013.06.032

Trimble M, Berkes F (2015) Towards adaptive co-management of smallscale fisheries in Uruguay and Brazil: lessons from using Ostrom's design principles. Marit Stud 14:1-20. https://doi.org/10.1186/ s40152-015-0032-y

Trimble M, Lázaro M (2014) Evaluation criteria for participatory research: insights from coastal Uruguay. Environ Manag 54:122137. https://doi.org/10.1007/s00267-014-0276-0

Turnhout E, Van Bommel S, Aarts N (2010) How participation creates citizens: participatory governance as performative practice. Ecol Soc. https://doi.org/10.5751/ES-03701-150426

Vaas J, Driessen PPJ, Giezen M, van Laerhoven F, Wassen MJ (2017) Who's in charge here anyway? Polycentric governance configurations and the development of policy on invasive alien species in the semi-sovereign Caribbean. Ecol Soc. https://doi.org/10.5751/ES09487-220401

Vaas J, Driessen PPJ, Giezen M, van Laerhoven F, Wassen MJ (2019) "Let me tell you your problems". Using Q methodology to elicit latent problem perceptions about invasive alien species. Geoforum. https://doi.org/10.1016/j.geoforum.2018.11.018

Valencia DH, Riera EM, I Juncà MB (2012) Participatory action research applied to the management of natural areas: the case study of Cinquera in El Salvador. J Lat Am Geogr. https://doi.org/10.1353/ lag.2012.0009

Ministerie van BZK (2018) Reactie Staatssecretaris Knops op de motie van de leden Van den Berg, Diertens, Bosman, Van der Graaf, Kuiken en Van Raak inzake innovatief land- en tuinbouwbeleid en voedselproductie op de BES-eilanden. Ministerie van Binnenlandse Zaken en Koninkrijksrelaties 2018-0000170580

van der Burg WJ, de Freitas JA, Debrot AO, Lotz LAP (2012) Naturalised and invasive alien plant species in the Caribbean Netherlands: status, distribution, threats, priorities and recommendations. PRI report 437. Imares report C185/11

van der Lely C, Warning AE, Schep SW, van Beukering P, Wolfs E (2014) The total economic value of nature on Saba R-14/11

Van Enst WI, Driessen PPJ, Runhaar HAC (2014) Towards productive science-policy interfaces: a research agenda. J Environ Assess Policy Manage. https://doi.org/10.1142/S1464333214500070

Ministerie van EZ (2017) Regelgeving Caribisch Nederland mbt dierenwelzijn Caribisch Nederland. Ministerie van Economische Zaken DGAN-DAD/17-21753

Hof van Justitie (2018) Saba. Vervolg op ECLI:NL:OGHACMB:2017: 96. Overheidsgrond. Verkrijgende verjaring. Bezit. Uitspraaknummer: ECLI:NL:OGHACMB:2018:31

Verbrugge LNH, Van Den Born RJG, Lenders HJR (2013) Exploring public perception of non-native species from a visions of nature perspective. Environ Manag 52:1562-1573. https://doi.org/10. 1007/s00267-013-0170-1

Waylen KA, Blackstock KL, Holstead KL (2015) How does legacy create sticking points for environmental management? Insights from challenges to implementation of the ecosystem approach. Ecol Soc. https://doi.org/10.5751/ES-07594-200221

Publisher's note Springer Nature remains neutral with regard to jurisdictional claims in published maps and institutional affiliations. 